\title{
Guide-assisted excision of the second branchial cleft fistula: a technical strategy
}

\author{
Rehber destekli ikinci brankiyal yarık kisti eksizyonu: Teknik bir strateji
}

\author{
Sedat Aydın, ${ }^{1}$ Mehmet Gökhan Demir ${ }^{2}$
}

${ }^{1}$ Department of Otolaryngology, Dr. Lütfi Kırdar Kartal Training and Research Hospital, İstanbul, Turkey

${ }^{2}$ Department of Otolaryngology, Prof. Dr. Celal Ertuğ Etimesgut State Hospital, Ankara Turkey

\begin{abstract}
Congenital neck masses are frequently observed neck masses; branchial anomalies constitute one of the most common reason. The most common branchial anomaly is type 2 lesions and majority of them are constituted by cysts. Branchial cleft fistula is rarely observed and appears with recurrent discharges in the clinic. The main treatment method is the exact surgical excision of the fistula tract. There are many methods defined for this purpose but the gold standard method is not found yet. Particularly, there are difficulties in the surgery, therefore fistula tract passes to important neurovascular tissues. Thus, we made apparent the fistula tract by using the lacrimal probe during the operation and excised it surgically. The patient's fistula was excised in an uncomplicated and safe way with this method.

Keywords: Congenital neck masses; guide-assisted method; second branchial fistula; surgical excision.
\end{abstract}

Many congenital masses are present in the head and neck area and $20-30 \%$ are formed by branchial anomalies. ${ }^{[1,2]}$ Cysts constitute $75 \%$ of branchial anomalies, while $25 \%$ are constituted by fistulas. Branchial cysts were first defined by Ascherson in 1832, and many theories have been implicated in their formation. The branchial apparatus theory, cervical sinus theory, pharyngeal theory and inclusion theory have been proposed, but the most widely accepted theory is that of incomplete branchial cleft and pouch closure in embryogenesis..$^{[2,4,5]}$ Most observed branchial clefts $(95 \%)$ are type 2 , followed by type $1(1-5 \%)$ as the second most common. ${ }^{[6]}$ We present a surgical excision
$\ddot{O} Z$

Doğuştan boyun kitleleri sıklıkla karşılaşılan boyun kitleleridir; brankial anomaliler bunların en sık nedenlerindendir. En sık görülen brankial anomalisi tip 2 lezyonlardır ve çoğunluğu kistlerden oluşmaktadır. Brankiyal yarık kisti nadiren gözlemlenir ve tedavide tekrarlayan deşarjlar ile görülür. Başlıca tedavi yöntemi, fistül yolunun kesin olarak cerrahi eksizyonudur. Bu amaçla tanımlanan birçok yöntem vardır ancak altın standart yöntem henüz bulunmamıştır. Özellikle cerrahide zorluklar vardır, bu nedenle fistül yolu önemli nörovasküler dokulara geçmektedir. Dolayısıyla, ameliyat sırasında lakrimal probu kullanılarak fistül yolu belirlendi ve cerrahi olarak çıkarıldı. Hastanın fistülü komplikasyon olmadan ve güvenli bir şekilde bu yöntem ile alındı.

Anahtar sözcükler: Doğuştan boyun kitleleri; rehber destekli yöntem; ikinci brankiyal kist; cerrahi eksizyon.

technique using lacrimal probe guides in a patient with type 2 branchial fistula.

\section{CASE REPORT}

A 24-year-old female patient was admitted to the otorhinolaryngology clinic with a complaint of swelling and discharge on the right side of the neck since childhood. The discharge appeared from time to time and did not respond to treatment. On physical examination, a soft mass over the medial sternocleidomastoid muscle border with an anteroinferior fistula opening $4 \mathrm{~cm}$ superior to the clavicle were observed on the right side 


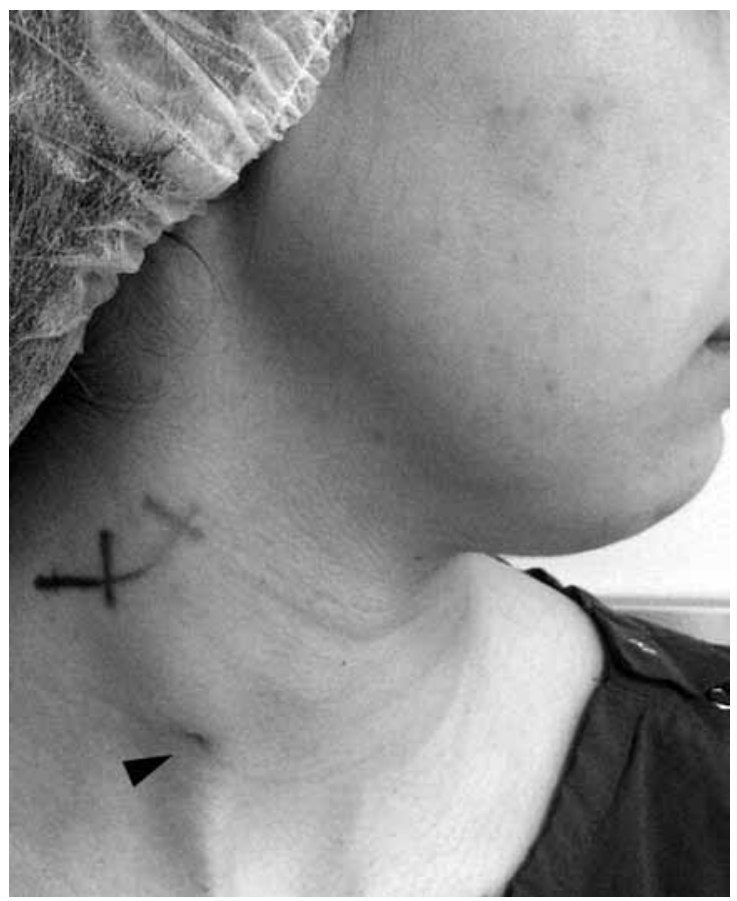

Figure 1. Preoperative image of the patient. The fistula opening of the patient located on the anterior border of right sided sternocleidomastoid muscle shown (black arrowhead).

of neck (Figure 1). Ultrasonography (USG) revealed the fistula tract to be $1.9 \mathrm{~mm}$ in diameter and could be traced to a depth of $5 \mathrm{~mm}$. Fistulography revealed the fistula tract from the line of the right thyroid lobe

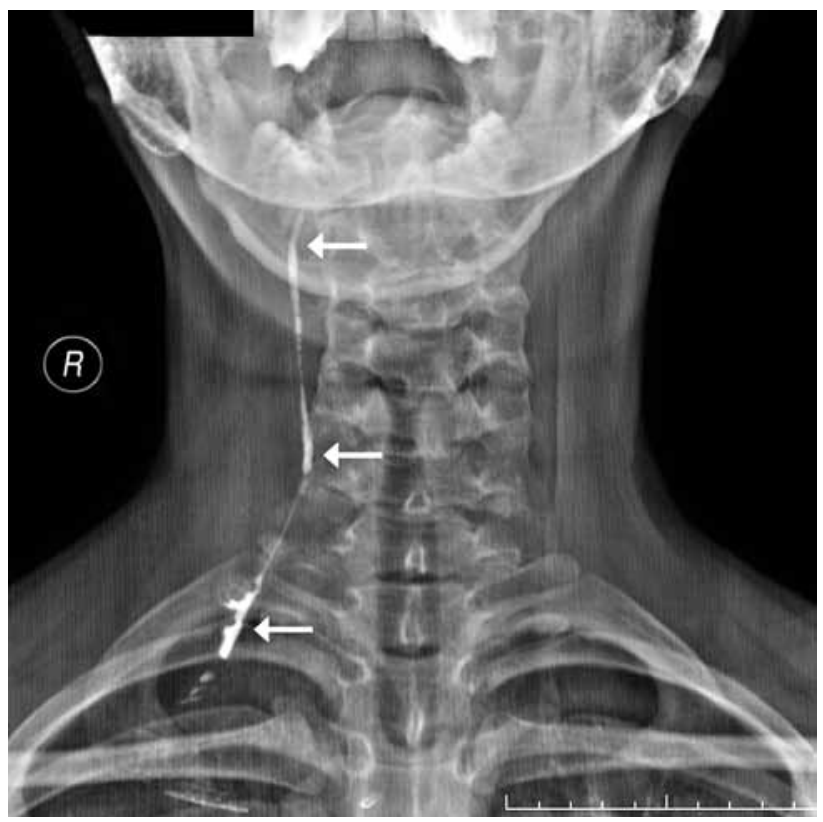

Figure 2. Preoperative anteroposterior fistulogram showing the fistula tract. on the right side of neck extending approximately 10 $\mathrm{cm}$ until the pharyngeal lateral wall and tongue base (Figure 2, 3). Written informed consent for publication was obtained from the patient.

\section{Surgical technique}

Under general anesthesia and following local infiltration, a fistula opening was observed in the skin over the middle third of right sternocleidomastoid muscle, at its anterior border. An approximately $4 \mathrm{~cm}$ fish-mouth incision was made parallel to skin creases around the fistula, including skin, subcutaneous tissue and platysma (Figure 4). The subplatysmal fistula tract was freed from surrounding tissues by sharp and blunt dissection. A lacrimal probe was inserted through the fistula opening so that the fistula tract became more apparent. After tracing the fistula tract vertically for approximately $4 \mathrm{~cm}$, a horizontal incision approximately $10 \mathrm{~cm}$ was made $2 \mathrm{~cm}$ inferior to the angle of the mandible, parallel to skin creases. The flaps were elevated in the subplatysmal plane. The tract was dissected from the first incision and freed from surrounding tissues until the second incision was reached (Figure 5). The tract passed the internal jugular vein superomedially, on the lateral side of the carotid bifurcation. The tract was bounded medially by the styloid process on the medial side of the stylohyoid muscle, and was amputated where it advanced deep to the external carotid artery (Figure 6). After hemostasis, penrose drains were placed to pass through both incisions, followed by closure with subcutaneous and skin sutures. Postoperative facial, accessory and hypoglossal nerve functions were normal. There was no recurrence or residual observed on one year follow-up.

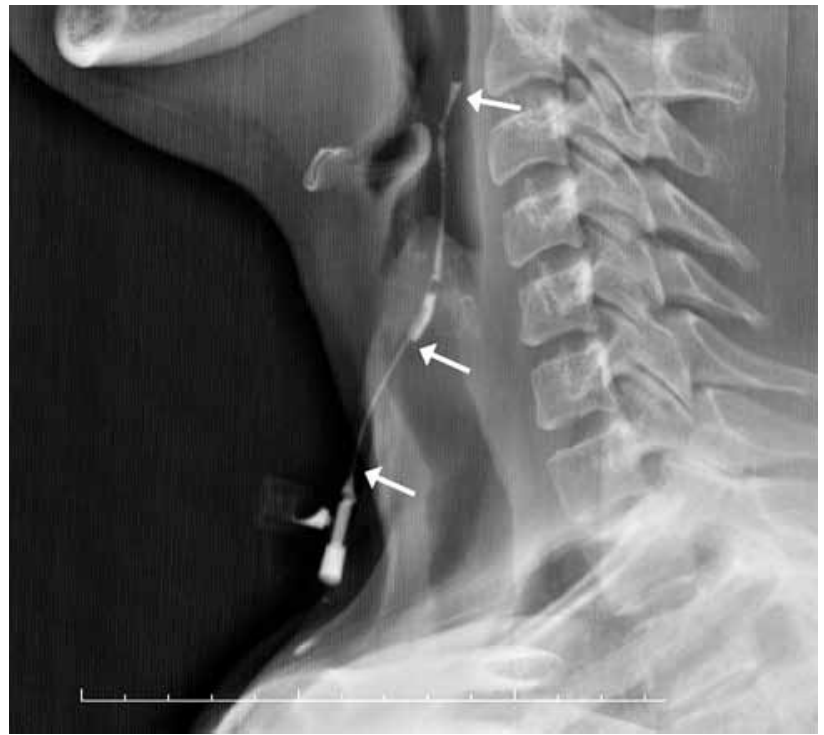

Figure 3. Preoperative lateral fistulogram image and fistula tract. 


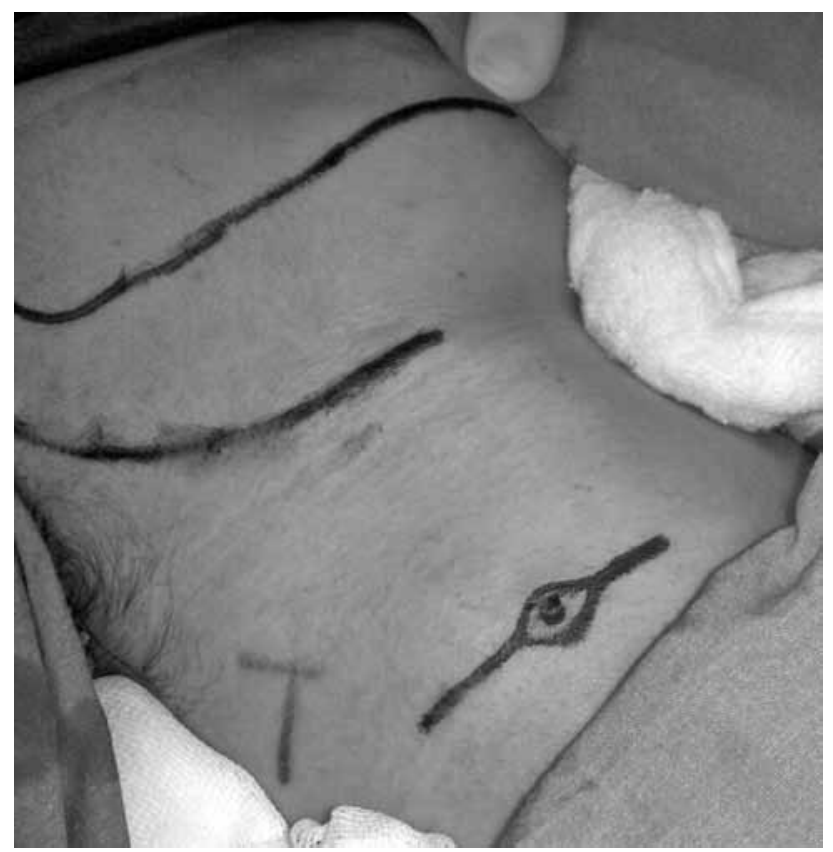

Figure 4. Intraoperative incision lines and fistula opening are marked.

\section{DISCUSSION}

While branchial anomalies constitute $20-30 \%$ of congenital neck masses, the most common of these lesions are type 2 anomalies. ${ }^{[7]}$ They consist of branchial apparatus arches, grooves and pouches. The branchial fistula is formed as a result of a defect in obliteration of groove and pouches. Branchial fistulas, generally encountered with swelling and discharge in the neck,

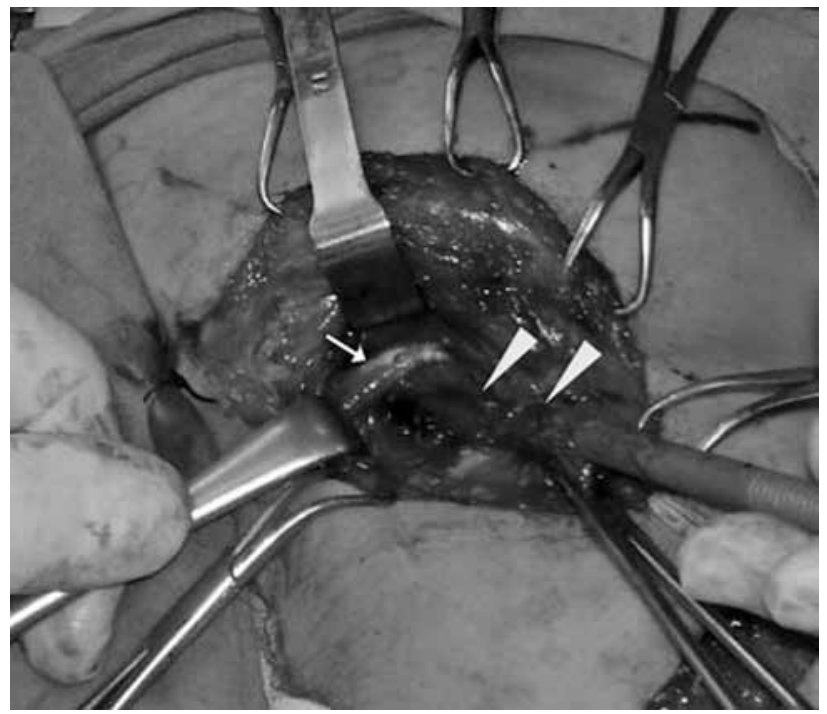

Figure 5. Tract dissected with an intraoperative guide and its apperance under two separate horizontal incision and flaps. are symptomatic at early ages. Patients are admitted to clinic during periods of infection with purulent discharge, and rarely have deep neck infections. ${ }^{[8]}$ The fistula opening may be observed along the anterior border of the sternocleidomastoid muscle in the neck and serous and/or purulent discharge upon manipulation may be observed on physical examination.

In the diagnosis of branchial fistula, fistula tracts may be observed by neck USG, but the benefits for diagnosis vary. ${ }^{[9,10]}$ In our patient, although the neck USG was helpful, it could not provide a definitive diagnosis. One of the most useful methods for diagnosis for most fistula is fistulography. In fistulography, the extension, length, relationship with neighboring anatomical areas and endpoint of the fistula tract may be determined. ${ }^{[11]}$ X-ray fistulography may be used in unidimensional assessment. Similarly computed tomography (CT) fistulography can be used in terms of anatomic assessment and three dimensional view of the fistula tract. ${ }^{[11]}$ The fistulography of our patient helped us in diagnosis and treatment.

Surgical excision is the most important treatment for branchial fistulas, and is recommended at a young age. Total excision of the fistula between ages 2-3 before recurrent infection and formation of fibrosis in surrounding tissue is generally the main treatment

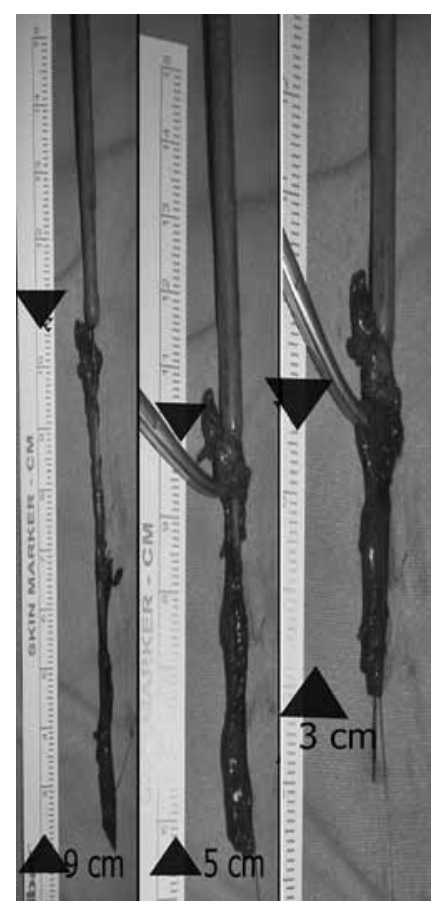

Figure 6. Appearance of the lacrimal probes in different lengths of fistula tract. 
recommendation. ${ }^{[12]}$ Surgical excision of the fistula tract constitutes challenges because of the lengthiness of the tract and its relation to anatomically important neurovascular structures.

So far, four surgical methods have been defined. ${ }^{[12]}$ The first method is a stepladder process aiming to provide extensive surgical exposure by two or more horizontal incisions. ${ }^{[12]}$ Using this method, methylene blue, liquid paraffin, or quick-hardening polymer may be used to determine the tract. Marking the tract with methylene blue is recommended in order to demonstrate it intraoperatively. However, as a result of material extension beyond the fistula, an error may occur in the exact location of the tract. ${ }^{[12]}$ Similar errors are possible using liquid paraffin and quick-hardening polymer. ${ }^{[12]}$

Second method is intraoperative fistulography. ${ }^{[12]}$ However, it was observed in the studies conducted that this method is not so useful for the surgeon. ${ }^{[12,13]}$ It also introduces an additional radiation burden on the patient. In the method we described, a lacrimal probe is inserted through the fistula opening. Thanks to its soft and flexible structure, this probe easily progresses along the tract and does not damage the fistula wall. The fistula tract becomes more apparent thanks to the probe, and may be easily dissected from surrounding tissues. By this method, important neurovascular structures are preserved and the tract is followed until the tonsillar fossa until the tonsillar fossa and, at the end, the tract is excised completely.

The third method involves a hockey-stick incision, through which a selective neck dissection can be performed, but we believe that the surgical approach at this level would be so huge. ${ }^{[13,14]}$

The fourth method involves excision of fistula tract with stripping. ${ }^{[15]}$ However, surrounding tissue can be damaged during stripping, increasing the possibility of fistula tract rupture and residual fistula. We avoid a similar case with this method.

Recurrence and reoperation rates after surgery of branchial fistulas range between $3-22 \%$ in diverse studies conducted. ${ }^{[12,16]}$ To prevent recurrence and residues we suggest that the tract should be apparent, the surgical dissection should be planned in this way and the operation should be avoided incase of infection. In the method we defined, the dissection of the plane is apparent, preventing residual fistulas. No recurrence or residual were observed on one year follow-up.

In conclusion, the most common group of branchial anomalies are type 2 lesions, of which fistulas constitute $25 \%$. The main complaints of patients are recurrent discharge and infection. There is no gold standard in diagnosis, but a fistulogram is the most beneficial method. The main treatment is surgical excision, the excision method we described, utilizing the lacrimal probe as a guide, may be a reliable method in preventing recurrence.

\section{Declaration of conflicting interests}

The authors declared no conflicts of interest with respect to the authorship and/or publication of this article.

\section{Funding}

The authors received no financial support for the research and/or authorship of this article.

\section{REFERENCES}

1. Enepekides DJ. Management of congenital anomalies of the neck. Facial Plast Surg Clin North Am 2001;9:131-45.

2. Waldhausen JH. Branchial cleft and arch anomalies in children. Semin Pediatr Surg. 2006;15:64-9.

3. Telander RL, Deane SA. Thyroglossal and branchial cleft cysts and sinuses. Surg Clin North Am 1977;57:77991.

4. Mitroi M, Dumitrescu D, Simionescu C, Popescu C, Mogoantă C, Cioroianu L, et al. Management of second branchial cleft anomalies. Rom J Morphol Embryol 2008;49:69-74.

5. Chandler JR, Mitchell B. Branchial cleft cysts, sinuses, and fistulas. Otolaryngol Clin North Am 1981;14:175-86.

6. Mounsey RA, Forte V, Friedberg J. First brachial cleft sinuses: an analysis of current management strategies and treatment outcomes. J Otolaryngol 1993;22:457-61.

7. Albers GD. Branchial anomalies. JAMA 1963;183:399409.

8. Nour YA, Hassan MH, Gaafar A, Eldaly A. Deep neck infections of congenital causes. Otolaryngol Head Neck Surg 2011;144:365-71.

9. Park SW, Han MH, Sung MH, Kim IO, Kim KH, Chang KH, et al. Neck infection associated with pyriform sinus fistula: imaging findings. AJNR Am J Neuroradiol 2000;21:817-22.

10. Shrime M, Kacker A, Bent J, Ward RF. Fourth branchial complex anomalies: a case series. Int J Pediatr Otorhinolaryngol 2003;67:1227-33.

11. Ryu CW, Lee JH, Lee HK, Lee DH, Choi CG, Kim SJ. Clinical usefulness of multidetector CT fistulography of branchial cleft fistula. Clin Imaging 2006;30:339-42.

12. Rattan KN, Rattan S, Parihar D, Gulia JS, Yadav SP. Second branchial cleft fistula: is fistulogram necessary for complete excision. Int J Pediatr Otorhinolaryngol 2006;70:1027-30.

13. Agaton-Bonilla FC, Gay-Escoda C. Diagnosis and treatment of branchial cleft cysts and fistulae. A retrospective study of 183 patients. Int J Oral Maxillofac Surg 1996;25:449-52. 
14. Cai Q, Pan Y, Xu Y, Liang F, Huang X, Jiang X, et al. Resection of recurrent branchial cleft deformity using selective neck dissection technique. Int J Pediatr Otorhinolaryngol 2014;78:1071-3.

15. Van Zele T, Katrien B, Philippe D, Hubert V. Stripping of a fistula for complete second branchial cleft. J Plast Reconstr Aesthet Surg 2010;63:1052-4.

16. Olusesi AD. Combined approach branchial sinusectomy: a new technique for excision of second branchial cleft sinus. J Laryngol Otol 2009;123:1166-8. 